Sign Systems Studies 33.2, 2005

\title{
Redefining national identity by playing with classics
}

\author{
Luule Epner \\ Department of Literature and Folklore, University of Tartu \\ Ülikooli 18, 50090 Tartu, Estonia \\ e-mail: luule.epner@ut.ee
}

\begin{abstract}
National identities are to a great extent based on common mythical stories (re)produced by literature and arts; in the long run, the core texts of literature themselves start to function as cultural myths. Performing classical works theatre relates them to the changing social context and thus actualises their meaning. Theatrical representations of national characters and mythical stories participate in reinforcing or redefining national identity. In independent Estonia of the 1990 s-2000s the need for reconsidering national values and myths that served to consolidate society in the Soviet period, has become evident. The article focuses on theatrical productions in the turn of the century, which are based on active rewriting of well-known Estonian classics (August Kitzberg, Oskar Luts, and the national epic Kalevipoeg). The article tries to answer two questions: how ingredients of national identity (for instance, the relation to the Other) are displayed and (de)constructed by adapting or rewriting of above-mentioned classics; how textual strategies aimed at semantic transformations are motivated and shaped by the principle of self-reflexive theatrical play.
\end{abstract}

\section{Introductory remarks}

This article deals with the study of interrelations of national identity, literary classics, and theatre, as exemplified by some Estonian stage productions of the 1990s-2000s. Although the building of a national identity with the help of the arts (including theatre) is a much-exploited research topic, it has not lost its importance at the beginning of the 21st century, but, quite the contrary, has gained new actuality because of social and cultural processes that are shaping contemporary world. 
People, states and nations are nowadays affected by two strong yet contrasting tendencies: globalization, expressed through economic and cultural standardization, similarities in lifestyles and more intense communications, and localization, which conversely stresses local uniqueness and strives to preserve or reproduce indigenous forms of culture and living. Their complex, partially paradoxical intertwinings are deeply influenced by cultural identity (including national identity as one of its dimensions), and on the other hand these processes place a great strain on the cultural identity. According to Rien T. Segers, the localization tendency is based on cultural identity, whereas the globalization tendency is driven mainly by technological and economic flows; he even speaks about a "cultural turn", meaning that contemporary developments, whether they have a global or a local nature, can not be understood without taking into account the concept of cultural identity (Segers 2004: 87).

Discussion about the impact of the current wave of globalization (which started in the late 1980s (Therborn 2000, as referred in Sevänen 2004a: 17)) is in fact closely linked to the discussion about postmodernity in the same period. Robert G. Dunn argues that the fragmentation of symbolic experience in postmodernity, together with cultural pluralization, lead to the destabilization of identities (Dunn 1998: 222-223). Speaking about the political changes that have taken place in the late 20th century, the sociologists have, in their turn, suggested that national identity is the most principal problem of the newly established post-communist countries (like Estonia): " $[\ldots] a$ fundamental question of transition for all East Europeans is "who are we?" (Lauristin 1997: 28). Whether we look at the past decades from the perspective of developments in globalization, postmodernity or postcommunism, the question of identity becomes the focal point. There is reason to discuss the problematization or crisis of traditional identities, accompanied by a need to reconstruct or readjust them. One way or the other, it is too early to cast the concept of national identity into the garbage heap of history as something old-fashioned and superseded in our "global village".

National identity, one of the most salient layers of the broader concept of cultural identity, is itself multi-dimensional. It is generally based on ethnic bonds, articulated in the people's belief in their common origin, but can not be reduced to them. According to Anthony D. Smith, the national identity is composed of a number of 
components: a historic territory (homeland); common myths and historical memories; a common, mass public culture; common legal rights and duties for all members; a common economy (Smith 1991: 14). It is evident that the relative importance of those components may vary across periods and/or nations. Common myths, historical narratives, traditions, values, beliefs etc. form the symbolic aspect of the national identity, which has been regarded as the most decisive for its durability, since it serves as a basis for the individual's emotional connection with the nation as a super-individual unity (Smith 1993: 162). Construction of the symbolic aspect of identity occurs to a great extent via representations produced by the arts. It has been noted that the creation of national myths by the arts has been exceptionally important in case of nations lacking political independence (Sevänen 2004b: 38); meaning that the relative weakness of one component is compensated with the (over)production of a cultural (symbolic) "generator". Estonia belongs amongst such nations; its national awakening took place in the second half of the 19th century, an independent nation was declared in 1918, only to be abolished again in 1940 by the Soviet occupation. The cornerstone of the Estonian national identity has generally been considered the Estonian culture, especially literature (see Veidemann 2004: 110). The less politic and economic freedom, the greater the need for unifying cultural events a claim supported by an unusually high prestige of the arts in the Estonian society, as well as the high nationalistic coding of theatre productions during the 19th century, during the dominion of German landlords as well as during the Soviet regime.

Let us resume: national identity as a part of cultural identity is not something primordial and inherent in the human nature, but is constructed during a process of socialization; representations of (idealized) national narratives and myths by the arts are of vital importance for producing and maintaining it. The means, options and the ways of operating vary to a great extent both on a historical as well as (artistic) morphological scale.

\section{Literature and theatre}

As was pointed out, literature has been considered the central factor in building up the Estonian identity, and it has been noted that the 
foremost goal of Estonian literature has been the production and reproduction of national and cultural identity, which in the 20th century is supplemented with attempts at creating the Estonian world literature (Undusk 1999: 249). One of the reasons is that literature is a language-based art - the Estonian language, not the geographical Estonia is regarded as the space of Estonian literature (Undusk 1999: 250) - , and the national language is the most important and sensitive component of the identity of a small nation. Secondly, the formation of a nation is to a great extent dependent upon the creation of a national narrative, partly composed by the works belonging to the literary classics (canon), that articulate national mentality or character, based on the collective self-image, as well as values and ideals regarded as characteristically national (concerning the relationship of literary canon and national identity, see Annus 2000). The figurative concept of a core or root text is used in Estonian literary criticism; such texts bring forth collective characteristics, desires and fears of the nation and form the "energetic field" of patriotic feelings (Veidemann 2003: 891). "Core" texts carry essential national myths through ages and, in their turn, in time they themselves begin to function as myths, becoming a part of the body of fictional stories the national selfconsciousness is resting upon. Examples of works, functioning as such myths, include the national epic Kalevipoeg, written by Fr. R. Kreutzwald (1853-1862), the drama The Werewolf (1912) by August Kitzberg, Springtime (1912-1913) together with its sequels by Oskar Luts, the novel Truth and Justice I-V (1926-1933) by Anton Hansen Tammsaare, ${ }^{1}$ poetry by Lydia Koidula, Juhan Liiv, etc. In addition, the treasury of common myths comprises mythologized biographies of writers such as Kristjan Jaak Peterson (the first Estonian poet who died very young), Lydia Koidula (a romantic poetess, the personification of Estonian patriotism, who died abroad), Juhan Liiv (the original Estonian "mad genius"), etc.

But what is the role of theatre in the creation of Estonian identity? The Estonian national theatre emerged during the 19th century (in 1870), led by the poetess Lydia Koidula. Theatre as an art form, i.e. a system of stage conventions and practices, did not stem from national culture (although theatrical games of singing and national traditions are not absent from the Estonian folklore), but was borrowed from the (Baltic) German culture. The role of the theatre, which had turned

1 English translations: Kreutzwald 1982; Kitzberg 1979; Luts 1983. 
professional in early 20th century, sprung from the European cultural system of the 19th century: the theatre is an institution of art for the purpose of performing and interpreting literary works. Initially, the Estonian theatre was untouched by the emancipatory movement of Western theatre taking place under the banner of a (re)theatralization. Supported mainly by the productions of original literary works, theatre has performed the task of producing national self-consciousness, working as a cultural amplifier of literary texts.

Attention should be paid to the specific manner of influence of the theatre art. First, the production and reception of theatrical performances is collective in nature. Due to this collective nature (sometimes even akin to a congregation), they have a strong emotional field of impact; theatre is a medium capable of amplifying the social field of influence of the otherwise "solitarily" received literary texts. Second, theatre is an institutional art. Loren Kruger has emphasized the character of theatre as a legitimate public sphere, and as a consequence, the appropriate site for nation building; it is not only a place, but also an occasion for the articulation of national prestige (Kruger 1992: 6-11). Of course, experimental performances of alternative theatres can form a part of the discourse of national identity as well as representative performances in big state theatres. Participation in a theatrical event can also be considered as a social ritual, where belief in a particular ethical-moral worldview is reinforced, and certain common myths are repeated (Paavolainen 1992: 15). ${ }^{2}$

The interrelation of theatre and literature in culture can also be described in terms of memory. According to Juri Lotman, culture is a collective intellect and a collective memory, a trans-personal mechanism for storing and exchanging texts, as well as for creation of new texts. The cultural space can indeed be outlined in terms of common memory. In the memory of the arts, which is of a creative type, the "forgetting" and "remembering" of pre-existing texts is taking place in a pulsating rhythm, the texts sometimes become actualized, sometimes fade (Lotman 1992: 200-201). This of course does not take place automatically. The theatre, bringing past works into the limelight -

\footnotetext{
2 In his research, Paavolainen brings out two myths important to the Finnish public of the 1960s: the myth of a united nation and the myth of a strong woman in control of her destiny. They are both carried by classic texts (Aleksis Kivi's Seven Brothers, Hella Wuolijoki's Niskamäe-series) and both are clearly supportive of identities (both national and gender).
} 
into the cultural consciousness of new generations - is for literature one of the mechanisms for "remembering", evaluation and re-evaluation. Staging as an intersemiotic translation of a literary text is also an active creation of relationships between the past texts and the temporally alternating social and ideological contexts of both the creators and the recipients of the stage production. Theatre (re)contextualizes literary texts, whereby the tradition of interpretation of the classic work and its author are part of the makeup the context, with which the new staging will inevitably form a dialogue. By updating the classics and activating new layers of meaning, theatre both preserves and renews the spiritual connection of the people with the legacy of the past.

When talking about theatre, its ephemeral and transient nature is often stressed (theatre is "written on sand"), yet on the other hand repetition and the tendency to recycle stories, characters, design elements etc. is also inherent to it. This side of theatre is pointed out by Marvin Carlson, who calls theatre a memory-machine and a repository of cultural memory - however, subject to continual modification as the memory is recalled in new circumstances (Carlson 2001: 2). Due to the close relationships between theatre and memory, national myths and historical stories utilize theatre to represent, reinscribe, and reinforce the nation as a cultural construction (Carlson 2001: 3).

The relation of theatre with literary classics is not limited to amplification and/or memory operations that suggest the primacy of conserving functions. Rather, stage productions balance between the two opposing attitudes: sometimes they insist on the present-day resonance of the classics, sometimes on their everlasting significance. Below, we examine how Estonian stage directors have treated Estonian classics at the turn of the 20th century.

\section{Stage production of The Werewolf by August Kitzberg}

During the Soviet period the Estonian theatre largely operated as a memory machine and a medium for manifestation of repressed national feelings. In the stage productions of the literary classics of the 1970 s to 1980 s the emphasis laid on the everlasting and the archetypal, articulated in criticism through the image of renewing 
contacts with national roots. This purpose was also served by some rewritings of classical texts aimed at purifying and intensifying their very core by means of a powerful ritualistic theatrical language, for example We Are Looking for Vargamäe based on Tammsaare's Truth and Justice (1976, directed by Kaarin Raid) or A People's War based on historical novels by Eduard Vilde (1981, directed by Jaan Tooming); characteristically they combined work-based themes with folklore. Although during the Soviet era stage productions of classics in an ironic key were also put on stage (e.g., by Mati Unt), these, nevertheless, were rather exceptional. One has to agree with Piret Kruuspere: typical of the 1980s was a unidimensional national pathos, replaced by a more ambiguous point of view in the next decade (Kruuspere 2000: 188).

The break in the Estonian political and economic system in the early 1990 s coincided with rather sharp changes in the spiritual atmosphere - the shift to the post-modern lifestyle and worldview. The situation in general was quite contradictory: the fight for independence boosted nationalism, yet at the same time in literature, for example, myths were deconstructed rather than created. As usual, theatre was more conservative compared to other forms of art; moreover so since the theatrical system remained principally the same. Upholding an extensive network of state-subsidized repertory theatres under the circumstances of the market economy (no state theatres were shut down) has even been called the "third way" of Estonia in the field of culture. The paradigm shifts mainly started to take place during the second half of the 1990s. The need for the double-coding of nationality, characteristic of the Soviet period, disappeared; the national self-consciousness ceased to consolidate the rapidly stratifying and unstable society of the so-called transition period. Thus, theatre lost its former role as a place of consolidation and had to reformulate its relationship with audiences. The market economy and the diversification of cultural consumption promoted more commercial productions. On the other hand, the need for reconsideration of national values from the present-day perspective has become a new challenge for the theatre.

The Estonian theatre of the 1990s has been reproached for avoiding the topics of social and political problems. In contrast, the national past is reinterpreted in a number of productions of both Estonian classics and original contemporary dramas, rewriting 
significant national myths. There are, of course, many traditional productions merely reproducing familiar stories and characters (e.g. the very popular open-air production of Truth and Justice I by A. H. Tammsaare (1997), performed at the writer's home farm, largely perceived as an "authentic" environment of the novel). However, besides these there are also productions the aim of which is a selfreflexive and critical dialogue with the national past. Among the most intriguing ones there are some rewritings of the "core" texts that perform a kind of deep ploughing on the field of national identity.

August Kitzberg's The Werewolf (1912) originates from the "golden era" of Estonian drama of the early decades of the 20th century. It is the most often produced Estonian play: approximately 40 stagings in professional Estonian theatres, as well as two screenings (one of them shot by exile Estonians living in the USA), and a ballet by Lydia Auster called Tiina. The story of the play takes place during the time of serfdom (19th century). The conflict between a young girl Tiina, aspiring for love and freedom, and the conservative village people (family of Tammaru) is motivated by her "foreign blood": different descent (Tiina's ancestors were free chiefs of people, her mother has been put to death as a witch), different appearance and temperament (a black-haired and hot-blooded girl versus the fairhaired and sluggish village people). Her otherness is emphasized by associations with wild nature, as opposed to human culture. As a consequence of a love intrigue she is publicly accused of being a werewolf and expelled from the village society; she stays living in the forest among the wolves. The play ends with Tiina's tragic death, struck by a bullet intended for a wolf. Kitzberg uses folklore in abundance: folk songs and games, chants, a scene during a Midsummer's Eve, which is one of the most important Estonian holidays, as well as the folk faith concerning werewolves.

The Werewolf functioned as a text constituting a national myth by presenting traditional culture and looking back to the ancient slavery. The impressive display of the people's mental life and of the ancient history was credited in synchronous criticism. The historic-ethnographic layer was probably one of the reasons why The Werewolf was chosen to represent the recently incorporated Estonia in the Moscow art decade of the Soviet Union, which was supposed to take place in 1941. Identity formation is more deeply affected by the grand opposition of Tiina and the Tammaru family, in which the idea of a personal 
freedom collides with the primeval wisdom demanding self-sacrifice for the survival of the people. This antagonism expresses the tragic dilemma of the Estonians, who have been living under the yoke of foreign powers for centuries: the burden and price of the preservation of the people, the inevitability and danger of the self-preservation programme (see Lauristin 1987: 51-52). Tiina performs the role of the exceptional and the alien, upon which the ideology of self-preservation leans. However, an alternative interpretation is also present in literary criticism, according to which it is the passionate Tiina who represents the primeval Estonian archetype, whose dionysian vitality cannot be extinguished by the imposed Christian worldview (Valgemäe 1990: 38). The Soviet-era stage productions of The Werewolf were concerned with the aforementioned dilemma, sometimes emphasizing the idea of freedom, sometimes the endurance.

In the 1990s, The Werewolf was staged twice in the Von Krahl Theatre, which has an avant-garde alternative theatre reputation, on both occasions by the leader of the theatre, Peeter Jalakas. Von Krahl, the first private theatre of the newly independent Estonia, was established in 1992 and its inaugural play was The Werewolf. Picking a classic core text was a symbolic gesture, which however did not manifest a continuing tradition but instead a desire to demolish cultural myths. The stage director was interested in unlocking the functional mechanics of cultural clichés. The Werewolf was used as a source for stereotypical situations, which the company of non-professional actors played in a comical-parodying key, accompanied by the stage director's commentaries played from tape. For the second time, Jalakas turned to Kitzberg's drama in 1998. As a matter of fact, it was The Werewolf based on Kitzberg, compiled by Jalakas himself and Margus Kasterpalu. Their basic strategy was to frame Kitzberg's story by means of the theatre-within-theatre technique: present-day actors just rehearse The Werewolf and discuss the play, as well as the situation and functions of the Estonian theatre in general. The production was defined as an experiment, and its main goal was clearly worded at the beginning of the performance: theatrical investigation of the validity of play's values and problems in today's society. The questions directing the production were specified in more detail in the programme; several of them concerned identity formation, for example: Why should the world care about Estonia? Why should Estonia care about the world? Are Estonians turning into Russians? 
Are Russians turning into Estonians? Does a border separate or unite? Etc.

In the course of the rehearsal on the stage, the actors tested different interpretative models, such as the realistic-psychological, the nationalromantic, the ritualistic, and finally rejected all of them as inappropriate from the contemporary perspective. The actress playing Tiina (Liina Vahtrik) showed up to the rehearsals later, as someone from outside just like her character, but her singularity was not insisted upon (externally she did not differ from the rest), so that her threatening and alien character was dependent upon psychological motivation, which the actors however could not find. The theatre-within-theatre technique was supplemented with a fragmented stage and stage activities, by which The Werewolf as a myth was split; its elements were inserted into multiple new contexts and related with metatextual commentary, both visual and verbal. First, a man called August (an allusion to August Kitzberg; played by Raivo E. Tamm) was sitting on a little platform above the stage (suggesting author's supremacy over the work). He read out Kitzberg's stage directions, some passages from the prose on the theme of werewolf by another writer, August Gailit, and quoted critical interpretations with regard to the play. Secondly, new technological media were used: the stage was fragmented with video and tele-screens, where different images and episodes were seen in parallel with the main stage activity. A large video screen at the back of the stage was reminiscent of a window, from which scenes of contemporary social reality could be seen: a populous city street, weird wolf-shaped figures, who were later identified as the outcasts of contemporary society, etc. The most significant image on the big video-screen was of a man walking through various landscapes and winding a string on a reel; at the end he was identified as a collector of frontiers (perhaps referring to the (future) Europe without frontiers). There was also a large television set on stage, in which an "investigation" of a slaughter of a foal was presented in the form of a parodic TV report - the leitmotif of the tragedy was drowned in a mass mysticism characteristic of a mass culture, so that it lost all credibility. On both the visual as well as the verbal level the opposition of human - wolf was elaborated (often in an ironic key), which was often analogous with the opposition own alien.

One of Jalakas's favourite techniques is a simultaneous combination of culturally, stylistically and ideologically different theatre 
signs, which support and/or cancel each other out. For example, in the Midsummer Eve scene, the actors jumped over a small television set placed on the floor, in which a bonfire was shown, and at the same time scenes from the movie The Werewolf by exile Estonians were shown on the big TV screen: modern theatrical play clashed with a rather naive-romantic film with its primitive ethnographism (dissonant, in its turn, with English subtitles). After that, a no less than fourfold combination was displayed: August's hysterically nationalist speech about the need to drive away the Russians (and to burn Tiina), in order to protect our blue-eyed race; a nationally emblematic man with a shepherd's horn on the centre stage; a seduction scene between Tiina and Margus carried out with wolf-like movements on the apron; everything accompanied by the music of Rammstein. The theatrewithin-theatre technique allowed the free fusion of elements of traditional, high and pop culture. The musical design was effectively eclectic: from Tchaikovsky's First piano concerto through nationalromantic songs to Rammstein. Such combinations revealed an antagonism between the modern and the mythical in the discourse of cultural and national identity.

Staging strategies and the fragmented stage enabled to split The Werewolf as a national myth, to explore its components by means of recontextualization and relating with metatexts - and to abandon it. First and foremost, the inadequacy of the sharp opposition between "us" and the "other" (with a special allusion to the relationship between Estonians and Russians) in modern society was emphasized. At the end of the performance the actors turned to the author (August), refusing to accept and perform the tragic conclusion of the play. The characters have become empty signs without any meaning, they say. So the classical story remained unfinished, the initial question was answered in the negative. The production can be viewed as a gesture of denial of a fossilized nationalism, and of an ideologized image of the Other as an enemy. At the same time, as a critic has remarked, it manifested a new, unfamiliar, and cosmopolite identity of a contemporary Estonian (Kruus 1998). However, the production did not initiate a wider discussion about identity, and the interest of the critics was focussed on the use of technological media. As a small hall production only played during a single season, it did not accumulate a lot of audience. 


\section{Two theatrical interpretations of the work of Oskar Luts}

Oskar Luts's novel Springtime, dating from the same period as The Werewolf (published in two parts in 1912-1913) portrays the life of schoolchildren - the beauty and pain of the first love, funny pranks, conflicts with German cadets, and so forth. Springtime, together with its sequels concerned with the further life of the same characters (Summer (1918-1919), Toots's Wedding (1921), Weekday (1924), Autumn (1938)) play a central role in the cultural consciousness of Estonians, primarily due to the colourful characters, who rapidly became well known to everyone. This was encouraged by numerous dramatizations, staged from 1930s onwards. Stagings of Oskar Luts belong to the core of Estonian theatre classics and have usually been very popular. (For example, from 1955-1965, three dramatizations of Oskar Luts led the attendance rankings (Toots's Wedding, Springtime and Summer) and the top ten included two more (Kask 1987: 465).) In addition to theatrical productions, there are also screenings, TV productions and Ülo Vinter's comic ballet Springtime.

Springtime has become a sort of a mythologeme of national discourse, referring to the "golden past", to the childhood of a nation, and to archetypal Estonians. A director Voldemar Panso, who staged Springtime in 1969, drew parallels with Seven Brothers by Aleksis Kivi: for him, the primordial soul of the Estonian nation finds its expression in Springtime, just as that of Finnish people is found in Seven Brothers (Panso 1969). The above-mentioned cycle by Luts has also been called a grand myth of the seasons, and an Estonian national allegory of the dance of life (Undusk 1994a). Luts has been considered as the Estonian national writer par excellence, who is loved by all Estonians, but hard to translate and hard to understand outside of the national cultural space. As a writer and a director Mati Unt has said: "Every nation has secret writers of its own, who grasp its originality with a particularly intimate authenticity" (Unt 1993: 91). The expectations of the theatre audiences have been led by the desire to meet "good old friends" from the pages of the books, to see familiar humorous stories, or to borrow the words of a critic: "It has become so intimate to the people that a change would bother" (Rosenvald 1984). 
However, at the second half of the 1990s, two strongly altered versions were staged: Winter by Madis Kõiv (1996, Vanemuine theatre, directed by Raivo Adlas) and Tonight We Play Ducks and Drakes by Mati Unt (1998, Estonian Drama Theatre, directed by Unt himself); the title of the latter makes a pun on the name of Luts (to play ducks and drakes $=$ to play 'luts') ${ }^{3}$. The creative impulse behind both productions seems to be the unique intimacy shared by the authors. Madis Kõiv considers Luts to be a constitutively relevant writer for Estonians; perhaps Estonians have shaped themselves according to Luts's characters, he smirked at a literary gathering. For Unt, Luts forms a part of his self-myth: they are united through the same childhood landscapes and being melancholic.

Winter and Tonight... are so-called "derived plays" (pièces dérivées, Tadeusz Kowzan), of which one domain is constituted by the rewriting of well-known classical texts. The concept of rewriting covers different far-reaching thematical and diegetic transformations, resulting in texts that stand in a complicated inter- and metatextual relationship with the primary texts and sometimes tend to function as an autonomous work. Matei Calinescu has pointed to post-modern sensitivity to the phenomena of textual transformations or rewriting, although it is by no means a monopoly of the post-moderns (Calinescu 1997: 247-248); in Estonian theatre this practice dates back to the modernist theatrical renewal in the late 1960s.

Winter is, as its title indicates, a continuation and the finale of Luts's cycle, following Autumn ${ }^{4}$. Kõiv inscribes the characters, these representative Estonians, into the period of the Soviet occupation and Stalinist repression of the 1940s. Winter, together with the imagery of snow and blizzard refers both to the death-phase of the cycle of the seasons and to the Stalinist period of history prior to the so-called "thaw", i.e. to the ruin of the good old times of national past, which in its turn are symbolized by "the spring" and "the summer" - from these Luts's works, extensive passages are quoted. Under the pressure of history, the national myth of the "golden past" (or the "old-time tale", as is said in Kõiv's text) breaks up. The stick-together

Unt has also written and directed a short play after Luts People in the Sauna (1999) and published his works on Luts's motifs as a collection titled Huntluts [Wolf-Burbot $]$ (1999).

Actually the title can be interpreted also as an allusion to the central character, whose name is Arno Tali (tali $=$ winter). 
community of the schoolchildren splits along different tracks of the historical destiny of Estonians: some of them become "forest brothers", desperately fighting against the Soviet rule (the prankster Toots), or deportees and refugees, some others become communist potentates or collaborators (Visak, who is an illegitimate child), and some try to creep into hiding in order to survive (Arno Tali). The characters on the stage seemed old, exhausted and tattered, being in sharp contrast with the original types in Oskar Luts's story. Similarly to The Werewolf, the writer (Oskar Luts, played by Ants Ander) himself was one of the characters - but as an author who has lost control over the world he has created, and forced to obey communist rulers (or - supremacy of the history?) himself.

The world of Winter undergoes rapid metamorphoses on account of alternation and blending of different layers of fictional time - that of the Springtime and the Summer and that of the 1940s. In some episodes this overlapping produced grotesque contamination. For example, the chrestomathic scene about Kiir's lost boot-buttons was presented in the form of a KGB interrogation: the schoolboys were threatened with deportation, Toots's fire hook turned out to be a rifle and cartridges were found instead of boot-buttons. The author, Oskar Luts, was forced to act as a transcript writer. The funny images of old times were crossed with rude violence of historical processes, and Luts's gentle humour was mixed with harsh Stalinist rhetoric, even on the level of sentences - for example, the parish clerk (a KGB agent in the reality of the 1940s) said to the students: "You better learn [Bible] verses and slogans!"

The temporally complex stage activity can also be interpreted as mental images or dreams of Arno Tali (Aivar Tommingas), in which the pressures of a collective subconscious find their expression. The subjectivity of temporal cognition was indicated by lighting design, alternating from all-encompassing darkness to full bright in images of the past. The people were portrayed not only as the victims of history, but collective guilt and fear was also illuminated. The splitting of the cast into two hostile camps was derived from the "golden past" itself: the boy who was bullied in Springtime became a Soviet militia in Winter, the son of a wealthy farmer became a well-groomed old gentleman in an American manner, i.e. a successful exile. The Arno of Winter wanted to take the blame for the eternal class struggle upon himself, to redeem the people from punishment. (The "translation" of 
causal processes into ethical categories of guilt and punishment is a recurring theme in Kõiv's work.) When the hope for a possible individual responsibility failed, he too, similarly to the characters of The Werewolf, turned to the author, and demanded him to be "taken back", as if he had never existed. Oskar Luts, as presented by Kõiv, is an author without power, who cannot change the past: "[...] which was, has been and is inevitable."

History (or the course of time) was denoted by several theatrical images: the snowdrift into which Arno was sinking (reminiscent of Happy Days by Beckett); the wind, flying banners and pictures of statesmen, etc. The monstrous, grotesque monument built of schooldesks with characters' faces appearing in its openings was the most impressive one, both evoking and concealing memories. It impressively visualized the metamorphoses of the myth of a national childhood under the impact of a historical experience of violence, and also functioned as an image of the work Springtime itself, which has become a sort of "cultural monument".

One of the main themes of this adaptation was memory individual, collective, and cultural. In the world of the play (that of the 1940s) it is dangerous to remember and to recognize each other during an interrogation, this would mean betrayal. The past has to be forgotten. The production spoke of an outrageous abolition of memory, ensuring the continuity of identity. In opposition to Luts's work, Winter began to manifest rupture, cleavage, and difference, both in the (historical) time and (social) space of Estonian nationalism. As for the reception, Winter provoked some perplexity, even indignation among the spectators. Already the open dress rehearsal caused polemics: is Springtime a proper basis for treating political issues and collective guilt of Estonians (Karja 1996). One protested against the demolition of a beloved myth. The audiences remained pretty small about 3400 spectators.

Mati Unt's productions of national classics have been characterized as sceptical "studies of the Estonian archetype" and the cultivation of a self-ironic view of a small nation's complexes (Kruuspere 2000: 193). Tonight We Play Ducks and Drakes is a comprehensive collage of about 25 works by Oskar Luts, as well as of documentary materials concerning the writer's biography and the reception of his works among critics. The so-called seasons-cycle constitutes the main line of the composition. The production's 
aesthetics were based on unconcealed playfulness and meta-theatricality: the fictional world was defined as a stage, where the actors perform situations originating from Luts's work. Initially, they were dressed in plain peasant tunics, later to be replaced with fashionable apparel. The stage design was laconic and functional, scenes were marked with scant items. The non-illusionist stage space was contrasted by scenes from the proto-landscapes for Springtime (Palamuse, Vooremaa), as a sign of "authenticity", projected onto a screen located at the back wall. The stage, divided into zones capable of smooth changes in meaning, would come to indicate the entire lived world of Estonians. The fictional time was just as all-inclusive. All of the layers of time - narrative, psychological, and theatrical behaved similarly, bringing forth repetitions and variations.

Similar to Kõiv, Unt too opened Luts's fictional world to the history but unlike Kõiv he accentuated historical recurrence, not rupture. History repeats itself: the crucial historical events of the 20th century fused into each other, and were performed as a series of variations on the basic conditions of the life of Estonians. With the help of a playful manipulation of time and space and pattern of repetitions, the overall history of the Estonian people in the 20th century - that of unending fight for independence, wars and subsequent rebuilding — was displayed in a slightly ironic manner. The mythical "golden past" of Estonians, too, broadened on account of the history. For instance, Luts's "old Russian time" was transferred onstage to refer both to the czarism and to the Soviet era; in this manner, the concept of the "golden past" itself as an object of permanent nostalgic yearning was highlighted. The purpose of the production's treatment of time and space was not a reiteration of a historical myth, but its mythical nature, i.e. the disclosure of the mechanisms constructing the myth.

A similar fusion could be observed in characters: stage figures were synthesized from several different characters from Luts's works, and often associated by means of intertextual techniques with different cultural texts. The premise was to define the environment of existence of the characters as a stage: "[...] the characters are neither lived nor historical, but are unfortunately real on the stage" (Unt 1999: 179). For example, Imesson "included" Imelik and Tõnisson from Springtime; the latter's patriotic hatred towards the Germans were emphasized by quotations from Eduard Bornhöhe's historic novel The 
Avenger, the protagonist of which is a symbolic figure of the national fight for freedom. Luts's comical Kiir was alternately quoting Hamlet and the amorous Bottom from A Midsummer Night's Dream. By fusing different characters, Unt reinforced their psychological dominants, so that they could be perceived as representations of national archetypes (or basic psychological types) on an international background. However, the actors were playing Luts's characters in an untraditional manner, sometimes even in direct contradiction with expectations: the feeble redhead Kiir (Taavi Eelmaa) was a stout and sturdy man of action, the melancholy dreamer Arno (Mait Malmsten) was played with a certain ironic distance, etc. The psychological summary of Estonians was in an uncanny displacement with Luts's "good old acquaintances", empathic identification was also hindered by a theatrically overblown manner of acting.

Similarly to Kõiv and Jalakas, Unt introduced the character of the author — Oskar Luts (Andrus Vaarik). The author was accompanied by his biography (inscribed into the text based on his diaries and other documentation), on account of which the fictional time embraced the Stalinist period from 1940 s to 1950 s; the campaign for uncovering "formalists" of that time as well as the fate of Luts's writer colleagues was incorporated through textual references. The Author in Unt's stage production was not primarily a commentator, but communicated actively with the other stage characters, sometimes from the author's (or rather, from the director's) position, and sometimes acted as a spectator, giving meaning of theatre-within-theatre to the scene.

From the viewpoint of identity formation one of the most intriguing supplements by Unt were two characters, acting in couple: the Russian Bolotov (Aleksander Eelmaa) and the German Sumpfentropf (Sulev Teppart). These were explicitly marked characters who embodied both the political forces that have determined the fate of Estonia (attention should be paid to the similarity of the names to those of Molotov and Ribbentrop, who contracted the infamous secret protocol) and cultural mentalities that have influenced Estonian culture. Their speech was full of cultural clichés; when one called in German Lebensraum!, the other replied in Russian Derzhava!, one Angst! Weltschmerz!, the other - Toska! Krassotaa spasayet mir!, one advocated Pushkin, the other Goethe, etc. Their thematic function was to perform the role of bog bogeys (from Luts's short story Bog; their names also have the $b o g$-stem). From an ideological perspective 
they appeared as aliens engraved into the collective subconscious ("the bog") of Estonians, who are fought but never disposed of. So the archetypal Other built into the mental space of a nation was made visible by theatrical means.

Unt's rewriting also thematized the status of Luts's works as classics: with fragments of criticism and the actors' memoirs inserted into the dialogue, which caused the "memory" of the text to emerge, or by performing some of the most famous phrases with an emphasis on demonstrating masterful acting, so that they sounded like quotations.

The reception of the stage production was quite controversial. It was well received by the critics, but attracted little audience, quite similar to Winter (less than 20 performances, about 3400 spectators), while the most popular production of Luts's work in the 1990s (The Backyard) gathered 21,000 spectators. ${ }^{5}$ The audiences seemed to prefer safe and familiar interpretations of classics.

\section{Kalevipoeg by Andrus Kivirähk}

With such a background in mind, the success of young writer Andrus Kivirähk's comedies paraphrasing national myths during the recent seasons is somewhat surprising. One of them, Kalevipoeg, was performed as an open-air production (2003, directed by Ain Prosa). Kivirähk's play is a parodic travesty of the Estonian national epic, compiled by Friedrich Reinhold Kreutzwald in the middle of the 19th century, and regarded as the national creative text, and ideological axis of the Estonian national spirit (Undusk 1994b: 148), even as a sacral text of Estonian literary culture (Veidemann 2003: 891). The cultural context of the stage production could have supported a sanctifying interpretation: 2003, the year in which two hundred years had passed since the birth of the creator of the epic, was declared Kreutzwald's Year, and the playing location was a landscape (Neeruti Sadulamägi), where, according to a folk legend, lie the furrows ploughed by Kalevipoeg. It is noteworthy that the Estonian political elite, including the President and the Prime Minister attended the

For comparison: the most successful stage production of the 1955-1965 period (Toots's Wedding) gathered 136,000 spectators. 
performances of Kalevipoeg. Yet the production counteracted the sacral context, operating more like a blasphemous counter-balance to an event organized the very same spring on the ancient Vallimägi in Rakvere, where approximately 80 volunteers (including the actors and actresses of the Theatre of Rakvere) recited the full text of Kalevipoeg during a 14 hour time span. The ritual recital, striving for a resuscitation of the epic in the collective memory, was contrasted by the bitter parody of the production. Parody, according to Linda Hutcheon, is a perfect post-modern genre, for it simultaneously incorporates and challenges its object (Hutcheon 1988: 11). The parodic stage production actualised the story of Kalevipoeg (extremely rarely performed in the Estonian drama theatre), but decisively redefined its characters and the motivation of events. On the stage, Kalevipoeg, the mythic king of Estonians, was not a powerful giant but an entirely ordinary young man of small height (played by Anti Reinthal), distinguished only by a sense of honour and responsibility. With the help of additional episodes originating from Kreutzwald's story Kilplased (an adaptation from the German folk book Schildbürger) common Estonians were depicted as being a fool-proud nation; the spirit of resistance of the nation degenerated into envious cursing and contempt for the rulers. The roles of the three men, representative of common people, were performed with coarse comic. Some heroic deeds of Kalevipoeg that have a rather negative impact, such as the killing of the son of a Finnish blacksmith, turned out to be the exaggerations of people's spiteful gossip. Some others, such as the defeat of the Devil, were resolved through purely theatrical tricks: the gigantic Devil, played by two actors inside the same costume, literally broke into pieces, when one of the actors dropped down from the other's shoulders. The prophetic closing lines of the epic (Kalevipoeg will return, to bring happiness to his children) were lies invented by the corpse-trading Hedgehog. The generative mechanisms of heroic tales were revealed, and meaning hence abolished; the production demonstrated in a comical manner the constructed nature of the national myths and demythologized them by shifting the viewpoint. In fact, two different demythologizing operations were executed. On the one hand, popular wisdom, expressed in utterances such as live simply and quietly and we are little people was mocked, and Estonians were cast in a poor light. On the other hand, the mythic Kalevipoeg was conveyed in a humane manner, freed from both the heroic aura as well 
as the belittling reputation of a dim-witted barbarian. Kivirähk's Kalevipoeg was a solemn peasant who experienced the tragic loneliness of a leader.

The problems of identity and the criticism of Estonian democracy in the stage production were pointed out in critical reviews, however a meta-theatrical level started to dominate: Kalevipoeg as a self-parody of a rag-tag summer theatre. For this purpose, Tuuslar (Andrus Vaarik) from the epic was turned into an aggressive entertainer who constantly tried to instigate both the actors and the spectators to play and merrymaking. The theatricality of the staging was emphasized by scenography (a small revolving stage amidst nature) and kitsch costumes. A small walk to the staging place preceding the performance, called a national expedition, during which the spectators could participate in folk games, sing folk songs and purchase Estonian handicraft products, showcased the rather ambivalent connection of nationality with commercial interests. Kalevipoeg was one of the most successful summer theatre productions in 2003 — about 12000 people watched the 15 performances - and as such it was more a social than an art event.

\section{Concluding remarks. Play}

The stage productions covered in this article are based on rewritings of core texts constructing the national identity. In the transitional society of Estonia in the 1990s, in which adaptations with an individualist mentality and the conditions of a market economy are taking place, the traditional national identity no longer has the power to unite people and to offer security. Some theatre practitioners have attempted to give new life to national myths with the help of their reproduction to big audiences, in order to make them experience national unity. Some others, presuming that theatre must reflect today's unstable world and fragmentation of identities, prefer to de- and reconstruct the traditional contents of identity.

Identity is constructed through relations with the alien/other. In this connection the reinterpretation of the sharp opposition between us vs. the strangers in terms of acceptance of the other and the different should be considered as being especially important (The Werewolf, Tonight...). It also concerns the relations inside the Estonian com- 
munity, considered not as a monolithic national body but as including inner discrepancies and differences (Winter, etc). National narrative includes an imbedded "golden past", the cultural representations of which are also several literary core texts. In theatrical adaptations, these are opened up to history and contemporary social reality through the support of an intertextual reference networks, demythologizing them (Winter, Tonight..., Kalevipoeg). It is in the power of theatre as a visual and activity-based art form to demolish through casting and manner of acting the stereotypes of the national character, embodied in characters and systems of figures of classical works, and to critically expose national psychology. This facet is relevant in Andrus Kivirähk's rather blasphemous texts. It seems that the popularity of his plays is on the one hand based on the recognition effect and on the other hand on the pleasure of laughing self-ironically at national sanctities. (It should be noted that through this they unavoidably cultivate the stereotype of a self-ironic Estonian.) So the abovementioned productions undermine the current myths and disclose the hang-ups and illusions of a small nation and by doing this encourage the self-conscious creation of identity, including national identity. The starting-point is the explication of myths forming the basis of identity as cultural constructs, in order to indicate that identity is not a selfevident and pregiven, but "made" and alterable.

Let us ask what sort of theatrical strategies are used in the stage productions described. First of all, the explicit "presence" ("visibility") of the theatre situation in these adaptations of the classics is noteworthy: they contain clear signals that tell the audience - this is a theatrical play (as opposed to the mimetic representation). Therefore, rewriting is coupled with meta-theatricality. According to Gérard Genette's Palimpsestes typology, we are dealing with semantic transformations that use and/or bring about a diegetic (transposition to a different spatio-temporal world) and a pragmatic (modification of events) transfer (see Genette 1982: 418). The initial stimulus for semantic changes is provided by the transposition into a world whose framework is formed by theatre-time and theatre-space that is the stage. The world of the production is firstly and openly defined as theatre. Diegetic transfer to the stage establishes initial conditions, which together with the openly playful nature of the activity motivate further transformations. Theatre is not regarded as a neutral medium for conveying classical works, but is presented as a specific situation 
of showing and looking. The action defined as play in a ludic space of theatre makes it possible to easily deconstruct and reconstruct fictional worlds. Klaus Schwind has argued that theatre play is an ambivalent, dynamic and genuinely dialogical process in which the spectator is an active co-player; it tends to complicate the structures and elements used in the play rather than simplify them, but it also makes them observable (Schwind 1997: 425). The theatre can play with texts, using them as game guidelines and playthings — playthings in the sense that due to the play they acquire new meanings, different from those that were valid before (Schwind 1997: 434). Playing as an explicit basic attitude motivates and permits the fragmentation of texts and putting of the elements into new contexts, created during the performance. Through play a strong present-day perspective can be established, the activity of playing splits cultural myths, opens new dimensions therein, and generates new meanings.

Theatre play (with the inscribed position of the spectator as a coplayer) may be seen as a mechanism for modelling cultural reality: "[...] theatre can be understood as an act of self-presentation and self-reflection on the part of the culture in question" (Fischer-Lichte 1992: 10). The productions under discussion thematize and foreground the theatrical act of cultural self-presentation in itself, using various staging and acting strategies. The explication of the theatre situation builds into the play a complementary reflective level. The status of literary core texts as cultural myths or monuments is indicated by stage images (Winter) and/or by bringing in previous interpretive models (Tonight..., The Werewolf). Characters of classical works as icons of national archetypes are interpreted and acted as theatrical roles, displaying the understanding of "the Estonian as a role" (see also Kruuspere 2000: 198). The demythologized character of the author is also included in the stage production (The Werewolf, Winter, Tonight...) as a creator who has forfeited the symbolic power over the work.

The play, as has been argued, needs co-players, i.e. spectators, but the audiences of the productions under discussion have mostly been rather small. In addition, theatre in general is shifting into a more peripheral sphere of social life of Estonians in the 1990-2000s. According to recent inquiries, $47 \%$ of Estonians have not visited theatre within a year (compared to $13 \%$ some twenty years ago); one can speak about a drastic decrease in cultural consumption in its 
entirety in the post-communist Estonia. ${ }^{6}$ Thus the impact on the processes of identity formation of the stage productions, crumbling the traditional national narrative by means of theatrical rewriting of the classics, cannot be overrated. The questions concerning who or where the most influential "architects and constructors" of national identity are in the present-day Estonian society, can obviously not to be answered within the frame of theatre studies alone.

\section{References}

Annus, Epp 2000. Kirjanduskaanon ja rahvuslik identiteet. Keel ja Kirjandus 1: $10-17$.

Calinescu, Matei 1997. Rewriting. In: Bertens, Hans; Fokkema, Douwe (eds.), International Postmodernism. Theory and Literary Practice. Amsterdam: John Benjamins Publishing Company, 243-248.

Carlson, Marvin 2001. The Haunted Stage: the Theatre as Memory Machine. Ann Arbor: The University of Michigan Press.

Dunn, Robert G. 1998. Identity Crises: A Social Critique of Postmodernity. Minneapolis: University of Minnesota Press.

Fischer-Lichte, Erika 1992. The Semiotics of Theater. Bloomington: Indiana University Press.

Genette, Gérard 1982. Palimpsestes. La littérature au second degré. Paris: Éditions du Seuil.

Hutcheon, Linda 1988. A Politics of Postmodernism: History, Theory, Fiction. New York: Routledge.

Karja, Sven 1996. Sürrealistlik Luts Vanemuises. Eesti Päevaleht 25.01.

Kask, Karin 1987. Eesti nõukogude teater 1940-1965. Sõnalavastus. Tallinn: Eesti Raamat.

Kitzberg August 1979 [1912]. The Werewolf. (Lepasaar, Merike, trans.) In: Straumanis, Alfreds (ed.), The Golden Steed: Seven Baltic Plays. Prospect Heights: Waveland Press, 228ff.

Kreutzwald, Friedrich Reinhold 1982. Kalevipoeg: An Ancient Estonian Tale. (Kurman, Jüri, trans.) Moorestown: Symposia Press.

Kruger, Loren 1992. The National Stage: Theatre and Cultural Legitimation in England, France, and America. Chicago: The University of Chicago Press.

Kruus, Martin 1998. Libahundi lahkumine lavalt. Postimees - Kultuur 23. 10.

Kruuspere, Piret 2000. The role of national theatre at the turn of the millennium: Estonian theatre interpreting Estonian literature in the 1990s. Interlitteraria 5: 86-199.

Lauristin, Marju 1987. Kestmine kui probleem. Teater. Muusika. Kino 6: 50-57.

6 See at http://www.kul.ee/failid/kultuuritarbimise_uuring_2003.rtf. 
- 1997. Contexts of transition. In: Lauristin, Marju; Vihalemm, Peeter; Rosengren, Karl Erik; Weibull, Lennart (eds.), Return to the Western World: Cultural and Political Perspectives on the Estonian Post-Communist Transition. Tartu: Tartu University Press, 25-40.

Lotman, Juri 1992 = Лотман, Юрий 1992. Память в культурологическом освещении. In: Лотман, Юрий, Избранные статьи I. Таллинн: Александра, 200-202.

Luts, Oskar 1983 [1912-1913]. Spring. (Jõgi, A.; Rauk, Melanie, trans.) Tallinn: Perioodika.

Paavolainen, Pentti 1992. Teatteri ja suuri muutto: ohjelmistot sosiaalisen murroksen osana 1959-1971. Helsinki: Kustannus Oy Teatteri.

Panso, Voldemar 1969. Varsti tuleb "Kevade". Sirp ja Vasar 21.02.

Rosenvald, Avo 1984. Vana armas Tootsi-lugu — aga ka midagi enamat. Edasi 16.12 .

Schwind, Klaus 1997. Theater im Spiel - Spiel im Theater. Weimarer Beiträge 43(3): 419-443.

Segers, Rien T. 2004. The underestimated strength of cultural identity between localising and globalising tendencies in the European Union. In: Kupiainen, Jari; Sevänen, Erkki; Stotesbury, John A. (eds.), Cultural Identity in Transition: Contemporary Conditions, Practices and Politics of a Global Phenomenon. New Delhi: Atlantic, 64-92.

Sevänen, Erkki 2004a. Introduction: From Modernity and Postmodernity to globalisation. In: Kupiainen, Jari; Sevänen, Erkki; Stotesbury, John A. (eds.), Cultural Identity in Transition: Contemporary Conditions, Practices and Politics of a Global Phenomenon. New Delhi: Atlantic, 1-30.

- 2004b. The study of cultural identity: Development and background of a multi-disciplinary field of research. In: Kupiainen, Jari; Sevänen, Erkki; Stotesbury, John A. (eds.), Cultural Identity in Transition:Contemporary Conditions,Practices and Politics of a Global Phenomenon. New Delhi: Atlantic, 33-63.

Smith, Anthony D. 1991. National Identity. Reno: The University of Nevada Press.

Undusk, Jaan 1994a. Ümberkirjutajad, torsotäiustajad, müüdimeistrid. Postimees 6.07 .

- 1994b. Rahvaluuleteksti lõppematus: Felix Oinas, soome meetod ja intertekstuaalne "Kalevipoeg". In: Oinas, Felix, Surematu Kalevipoeg. Tallinn: Keele ja Kirjanduse raamatusari, nr 1, 147-174.

- 1999. Eesti kirjanduse ajast, ruumist ja ülesandest XX sajandil. Looming 2: 249-255.

Unt, Mati 1993. Argimütoloogia sõnastik 1988-1993. Tallinn: Kupar.

- 1999. Huntluts. Teoseid Oskar Lutsu motiividel. Tallinn: Kupar.

Valgemäe, Mardi 1990. Rituaalteatrist ja "Libahundist". In: Valgemäe, Mardi, Ikka teatrist mõteldes. Stockholm: Välis-Eesti \& EMP, 30-40.

Veidemann, Rein 2003. F. R. Kreutzwaldi "Kalevipoeg" kui eesti kirjanduskultuuri sakraaltekst. Keel ja Kirjandus 12: 891-896. 
- 2004. Marginality and the renewal of independence in Estonia. In: Kupiainen, Jari; Sevänen, Erkki; Stotesbury, John A. (eds.), Cultural Identity in Transition: Contemporary Conditions, Practices and Politics of a Global Phenomenon. New Delhi: Atlantic, 105-122.

\section{О переформулировании национального идентитета с помощью игры с классиками}

Национальный идентитет в большой мере основывается на общих мифах, (вос)производимыми литературными и художественными произведениями, которые в течение времени могут сами начать функционировать в качестве национальных культурных мифов. В постановках классических произведений театр соотносит эти мифы с постоянно изменяющимся социальным контекстом и обновляет, опровергает или вновь подтверждает их смыслы. Театральные репрезентации актуальных для нации нарративов и типов персонажей является частью механизма создания идентитета. В 1990-2000 гг. национальные ценности и общие мифы, которые в советское время сплачивали общество, утратили свою консолидирующую силу. В статье рассматриваются постановки эстонского современного театра, которые основываются на активном переписывании эстонской классики (Август Китцберг, Оскар Лутс, национальный эпос Калевипоэг), и пытаются ответить на два вороса: как составляющие национального идентитета (например, отношение к Другому) представлены и (де)конструированы при адаптации или переписывании вышеназванной классики; как текстовые стратегии приводят к семантическим транформациям, вызванным игровым характером театрального действа.

\section{Rahvusliku identiteedi uuestimääratlemisest klassikamängude kaudu}

Rahvuslik identiteet on suurel määral rajatud ühistele müütidele, mida (taas)kujutavad kirjandus- ja kunstiteosed, mis aja jooksul võivad ise hakata funtsioneerima rahvuslike kultuurimüütidena. Kodumaist klassikat lavastades suhestab teater neid müüte pidevalt muutuva sotsiaalse kontekstiga ning uuendab, kummutab või taaskinnitab nende tähendusi. Rahvuse jaoks oluliste lugude ja tegelastüüpide teatraalsed representatsioonid on üks osa identiteediloome mehhanismidest. 1990.-2000. aastate Eestis on rahvuslikud väärtused ja ühismüüdid, mis nõukogude ajal ühiskonda 
koos hoidsid, minetanud oma endise konsolideeriva jõu ning kuuluvad küsimuse alla seadmisele. Käesolevas artiklis vaadeldakse eesti nüüdisteatri lavastusi, mis põhinevad Oskar Lutsu proosa, August Kitzbergi tragöödia "Libahunt" ning rahvuseepose "Kalevipoeg" ülekirjutustel: "Libahunt" (lav Peeter Jalakas, 1998), Madis Kõivu Lutsu-aineline "Tali" (lav Raivo Adlas, 1996) ja Mati Undi “Täna õhta viskame lutsu” (lav Mati Unt, 1998), Andrus Kivirähki "Kalevipoeg” (lav Ain Prosa, 2003). Kui 1980. aastate eesti teatrile oli tüüpiline rahvuslik paatos ja identiteedi kinnitamine, siis järgmiste kümnendite üleminekuühiskonnas, kus toimub kohanemine globaliseerumise, multikultuurilisuse ideoloogia jm uute mõjuteguritega, on teatri toimimine identiteediloomes muutunud mitmeplaanilisemaks ja keerukamaks. Tähelepanu väärib oma - võõra konfliktse vastanduse ümbertõlgendamine teise ning erineva aktsepteerimise vaimus ("Libahunt”, "Täna õhta..."). "Kuldse mineviku” müüt, mida mitmed klassikateosed representeerivad, avatakse teatriadaptsioonides intertekstuaalse viitevõrgustiku varal nii ajaloole kui ka tänapäeva sotsiaalsele tegelikkusele, ning seeläbi demütologiseeritakse ("Tali", "Täna õhta...", "Kalevipoeg"). Teatri kui visuaalse ja tegevusliku kunsti võimuses on samuti osajaotuse ja näitlejate mängulaadi toel lammutada rahvusliku karakteri stereotüüpe ning kriitiliselt valgustada rahvuslikku psühholoogiat. Vaadeldud lavastused eksplitseerivad identiteeti põhistavaid müüte kui kultuurilisi konstruktsioone ning näitavad, et identiteet ei ole etteantud, vaid "tehtud" ja muudetav. Tekstiloome seisukohast köidab tähelepanu alustekstide ülekirjutamine ja lavastamine nii, et selgelt tuuakse nähtavale teatrisituatsioon; lavategevus kätkeb ilmseid signaale, et tegemist on teatrimängu, mitte mimeetilise reproduktsiooniga. Klassikat n-ö mängulises režiimis esitavad lavastused lammutavad kultuurimüüte ja toovad neis esile uusi ulatuvusi. 